\title{
OPEN Sustainable intensification of maize and wheat cropping system through pulse intercropping
}

\author{
S. C. Tripathi ${ }^{\bowtie}$, Karnam Venkatesh, Raj Pal Meena, Subhash Chander \& G. P. Singh
}

The intercropping of legumes with cereals help to achieve sustainable intensification by their mutual complementarity at efficiently using radiation, nutrients, etc. Several studies indicated such beneficial effects on the other component crop however, little research has been conducted to quantify their effects on the subsequent crop in a cropping system. In this study, the effect of the legume intercropping on the entire cropping system, particularly the maize + legume-wheat system was studied. Four legumes intercropped to maize followed by wheat crop were studied for intensification measures such as wheat equivalent yield (WEY), land equivalent ratio (LER), sustainable value index (SVI), and economic returns. $\mathrm{N}$ saving effect of legumes on the subsequent wheat crop was quantified with two $\mathrm{N}$ levels. Maize + cowpea-wheat combination was the most productive and economic intercrop combination (LER $=1.71, \mathrm{SVI}=0.96$ ) with an increase in net economic return $(43.63 \%)$ with a $\mathrm{B}: \mathrm{C}$ ratio of 1.94 . An additional $25 \% \mathrm{~N}\left(37.5 \mathrm{~kg} \mathrm{ha}^{-1}\right)$ was saved in the wheat crop when the legume intercropping was undertaken with maize. The results suggest that intercropping is the key to diversification and reduces the risk of crop failures by enhancing land-use efficiency, soil fertility, and economic returns under weather vagaries. This will be beneficial to small and marginal farmers of many countries.

The major goal of agriculture during the current times is sustainably increasing food production without harming the environment ${ }^{1}$. Intensive mono-cropping of cereals globally has contributed to increased production of staple crops but at the cost of disturbance to the ecological balance in terms of causing pollution, overexploitation of resources etc ${ }^{2-4}$. Latest innovations in agronomy such as intercropping have contributed to enhanced land utilization by efficiently choosing crop species with complementarity for space, radiation, and input usage ${ }^{5}$. Intercropping was proven to help in improving resource capture and utilization, soil fertility, and reduce soil erosion ${ }^{6,7}$. Two crops with different canopy coverage, architecture, and growing periods enhance radiation use efficiency by reducing the light reaching the ground ${ }^{5}$. Maize/soybean ${ }^{5,8}$, maize/cowpea $^{9,10}$ and maize/peanut ${ }^{11,12}$ are the examples for such intercrops.

Globally, maize has a significant area under cultivation (197.23 mha) and out of which $73 \%$ is occupied by developing countries. Some of the countries like China (41.31 mha), the USA (32.95 mha), Brazil (17.52 mha), India (9.03 mha), Argentina (7.23 mha), South Africa $(2.30 \mathrm{mha})$, and Ethiopia $(2.27 \mathrm{mha})$, etc. have a great scope of intercropping owing to their high maize acreage and mechanized form of seeding ${ }^{13}$. Maize is preceded by wheat in many counties like China, India, Mexico, and Pakistan, etc. Maize constitutes $6.5 \%$ of the food supplies in Asia and thus is a major contributor to food security of the region ${ }^{14}$. Identification and development of agronomic manipulations and mechanisms such as cereal + pulse intercropping may enhance the sustainability of maize-based cropping systems worldwide. Maize/pulse intercropping can significantly reduce the competition for land resources between maize and legumes can help in simultaneously increasing the production of both crops $^{15}$. Additional pulses produced through intercropping can contribute to overall enhanced pulse production. India is home to the largest pulse-consuming population globally ${ }^{16}$ and $20 \%$ of its demand is met by imports valued to the tune of 3800 USD in $2016-2017^{17}$.

Intercropping of pulses with maize was found to be advantageous to maize and however, little research has been conducted to quantify their effects on the subsequent crop in a cropping system. The reported favorable effects of the pulse intercropping with cereals include high carbon sequestration, higher water use efficiency, nitrogen transfer to the subsequent $\operatorname{crop}^{18}$, improve soil biodiversity etc ${ }^{19}$. Therefore, the study was designed to study the effect of the pulse intercropping with maize on system yield and quantification of the $\mathrm{N}$ saved in the subsequent wheat crop. 

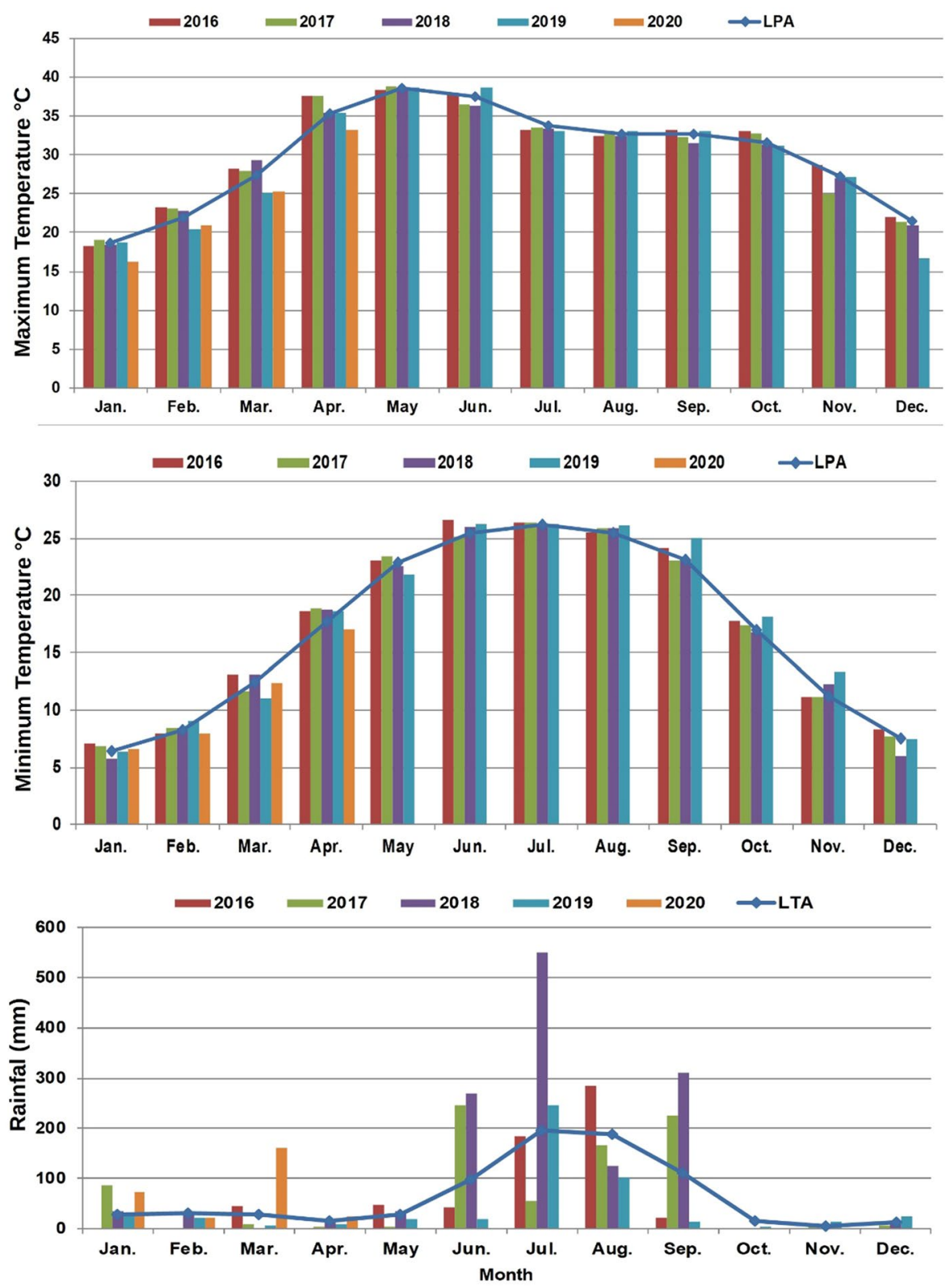

Figure 1. Maximum and minimum temperature and rainfall during the crop years.

\section{Materials and methods}

Study site and soil characteristics. A field experiment was conducted during 2016-2017 to 2019-2020 at the research farm of ICAR-Indian Institute of Wheat and Barley Research, Karnal, Haryana, India $\left(29^{\circ} 43^{\prime} \mathrm{N}\right.$, $76^{\circ} 58^{\prime} \mathrm{E}, 245 \mathrm{~m}$ above sea level). The weather during July to October remains hot and humid, and most of the precipitation (75-80\%) occurs during this period. The soil was moderately well-drained coarse-textured sandy loam ( $11.1 \%$ clay, $26.5 \%$ silt, $62.4 \%$ sand) with low to moderate fertility. Baseline soil samples were collected (0-15 cm depth) from each test site at the start of the experiment (2016-2017) and after completion of four crop cycles and analyzed for $\mathrm{pH}$ (using a soil water solution of 1:2.5 wt/v), soil organic carbon ${ }^{20}$, available $\mathrm{N}^{21}$, available $\mathrm{P}^{22}$, and available $\mathrm{K}^{23}$. The soil was having $111.88 \mathrm{~kg} \mathrm{ha}^{-1}$ available $\mathrm{N}, 0.35 \%$ organic carbon, $12.37 \mathrm{~kg} \mathrm{ha}^{-1}$ available $\mathrm{P}$, and $155.9 \mathrm{~kg} \mathrm{ha}^{-1}$ available $\mathrm{K}$ with an alkaline $\mathrm{pH}$ of 8.44 and $\mathrm{EC}$ of $0.12 \mathrm{dS} \mathrm{m}^{-1}$.

Meteorological conditions. The data on important weather parameters such as daily minimum, maximum temperature, and precipitation were recorded throughout the crop season during the experimental years. The long-term weather data from 1981 to 2018 were collected from the data repository maintained by ICARCentral Soil Salinity Research Institute, Karnal. The monthly temperature (minimum and maximum) and precipitation data were used to calculate the long-term average values. The weather information is presented in the graph (Fig. 1). The highest precipitation was recorded in the year 2020, and the lowest was recorded in the year 


\begin{tabular}{|c|c|c|c|c|}
\hline & \multirow[b]{2}{*}{ Treatments } & \multirow[b]{2}{*}{ Crops grown } & \multicolumn{2}{|c|}{ Annual fertilizer application $\left(\mathrm{kg} \mathrm{ha}^{-1}\right)$} \\
\hline & & & Maize/pulses & Wheat \\
\hline 1 & MGW100 & Maize + green gram - wheat & $150 \mathrm{~N}, 60 \mathrm{P}_{2} \mathrm{O}_{5}, 40 \mathrm{~K}_{2} 0$ & $150 \mathrm{~N}, 60 \mathrm{P}_{2} \mathrm{O}_{5}, 40 \mathrm{~K}_{2} 0$ \\
\hline 2 & MGW75 & Maize + green gram - wheat & $150 \mathrm{~N}, 60 \mathrm{P}_{2} \mathrm{O}_{5}, 40 \mathrm{~K}_{2} 0$ & $112.5 \mathrm{~N}, 60 \mathrm{P}_{2} \mathrm{O}_{5}, 40 \mathrm{~K}_{2} 0$ \\
\hline 3 & MBW100 & Maize + black gram - wheat & $150 \mathrm{~N}, 60 \mathrm{P}_{2} \mathrm{O}_{5}, 40 \mathrm{~K}_{2} 0$ & $150 \mathrm{~N}, 60 \mathrm{P}_{2} \mathrm{O}_{5}, 40 \mathrm{~K}_{2} 0$ \\
\hline 4 & MBW75 & Maize + black gram - wheat & $150 \mathrm{~N}, 60 \mathrm{P}_{2} \mathrm{O}_{5}, 40 \mathrm{~K}_{2} 0$ & $112.5 \mathrm{~N}, 60 \mathrm{P}_{2} \mathrm{O}_{5}, 40 \mathrm{~K}_{2} \mathrm{O}$ \\
\hline 5 & MCW100 & Maize + cluster bean - wheat & $150 \mathrm{~N}, 60 \mathrm{P}_{2} \mathrm{O}_{5}, 40 \mathrm{~K}_{2} 0$ & $150 \mathrm{~N}, 60 \mathrm{P}_{2} \mathrm{O}_{5}, 40 \mathrm{~K}_{2} 0$ \\
\hline 6 & MCW75 & Maize + cluster bean - wheat & $150 \mathrm{~N}, 60 \mathrm{P}_{2} \mathrm{O}_{5}, 40 \mathrm{~K}_{2} 0$ & $112.5 \mathrm{~N}, 60 \mathrm{P}_{2} \mathrm{O}_{5}, 40 \mathrm{~K}_{2} 0$ \\
\hline 7 & MCowW100 & Maize + cowpea - wheat & $150 \mathrm{~N}, 60 \mathrm{P}_{2} \mathrm{O}_{5}, 40 \mathrm{~K}_{2} 0$ & $150 \mathrm{~N}, 60 \mathrm{P}_{2} \mathrm{O}_{5}, 40 \mathrm{~K}_{2} 0$ \\
\hline 8 & MCowW75 & Maize + cowpea - wheat & $150 \mathrm{~N}, 60 \mathrm{P}_{2} \mathrm{O}_{5}, 40 \mathrm{~K}_{2} 0$ & $112.5 \mathrm{~N}, 60 \mathrm{P}_{2} \mathrm{O}_{5}, 40 \mathrm{~K}_{2} 0$ \\
\hline 9 & MW & Maize-wheat & $150 \mathrm{~N}, 60 \mathrm{P}_{2} \mathrm{O}_{5}, 40 \mathrm{~K}_{2} 0$ & $150 \mathrm{~N}, 60 \mathrm{P}_{2} \mathrm{O}_{5}, 40 \mathrm{~K}_{2} 0$ \\
\hline 10 & GW & Green gram - wheat & $20 \mathrm{~N}, 50 \mathrm{P}_{2} \mathrm{O}_{5}$ & $112.5 \mathrm{~N}, 60 \mathrm{P}_{2} \mathrm{O}_{5}, 40 \mathrm{~K}_{2} 0$ \\
\hline 11 & BW & Black gram- wheat & $20 \mathrm{~N}, 50 \mathrm{P}_{2} \mathrm{O}_{5}$ & $112.5 \mathrm{~N}, 60 \mathrm{P}_{2} \mathrm{O}_{5}, 40 \mathrm{~K}_{2} 0$ \\
\hline 12 & $\mathrm{CW}$ & Cluster bean - wheat & $20 \mathrm{~N}, 50 \mathrm{P}_{2} \mathrm{O}_{5}$ & $112.5 \mathrm{~N}, 60 \mathrm{P}_{2} \mathrm{O}_{5}, 40 \mathrm{~K}_{2} 0$ \\
\hline 13 & CowW & Cowpea-wheat & $20 \mathrm{~N}, 50 \mathrm{P}_{2} \mathrm{O}_{5}$ & $112.5 \mathrm{~N}, 60 \mathrm{P}_{2} \mathrm{O}_{5}, 40 \mathrm{~K}_{2} 0$ \\
\hline
\end{tabular}

Table 1. Treatment details of the long term irrigated maize + pulses-wheat intercropping system.

2016. July month, starting monsoon month of the year received the maximum rainfall and particularly it was highest in 2019, even higher than the long term average. In 2019 and 2020, the maximum temperature from February to April was lower than that of other years whereas there was no difference in minimum temperature. In contrast, the first 2 years' maximum and minimum temperature of March and April was higher than the longterm average.

Experimental design, treatments and crop management. The experimental design adopted was a randomized block design with 3 replications and consisted of 13 treatments (Table 1). Four legumes i.e. green gram (variety SML 668), black gram (variety T-9), cluster bean (variety HG 365), and cowpea (variety PusaKomal) were used in this study, and cultivars were collected from the local market. Authors comply with the IUCN Policy Statement on Research Involving Species at Risk of Extinction and the Convention on the Trade in Endangered Species of Wild Fauna and Flora. Four legumes i.e. green gram, black gram, cluster bean, and cowpea were intercropped with maize crop in 1:1 ratio and a sole crop also was planted as control. During the summer season, maize, green gram, black gram, cluster bean, and cowpea were grown sole crop as well as intercrop. Maize variety X 92 (hybrid) with seed rate of $25 \mathrm{~kg} \mathrm{ha}^{-1}$, green gram variety SML 668 with seed rate $20 \mathrm{~kg} \mathrm{ha}^{-1}$, black gram variety T-9 with seed rate of $20 \mathrm{~kg} \mathrm{ha}^{-1}$, cluster bean variety HG 365 with seed rate of $10 \mathrm{~kg} \mathrm{ha}^{-1}$ and cowpea variety Pusa Komal with seed rate of $25 \mathrm{~kg} \mathrm{ha}^{-1}$ were used. Wheat variety HD 3086 was seeded during the winter season with a seed rate of $100 \mathrm{~kg} \mathrm{ha}^{-1}$. Wheat crop was grown in plots where previous crops was the sole legume, $112.5 \mathrm{~kg} \mathrm{~N}$ was applied. In maize crop a uniform fertilizer rate of $150 \mathrm{~kg} \mathrm{~N}, 60 \mathrm{~kg} \mathrm{P}_{2} \mathrm{O}_{5}$ and 40 $\mathrm{K}_{2} \mathrm{O} \mathrm{kg} \mathrm{ha}{ }^{-1}$ was applied to avoid any nutrient stress as per the recommended package of practices ${ }^{24}$. The whole quantity of phosphorus and potassium and one-third of $\mathrm{N}$ was applied as basal dose through urea, diammonium phosphate, and muriate of potash. The remaining $\mathrm{N}$ was applied as top dressing in two equal splits, DC31 and DC $41^{25}$. Treatments having sole legume crops were applied with $20 \mathrm{~kg} \mathrm{~N} \mathrm{ha}^{-1}$ and $50 \mathrm{~kg} \mathrm{P}_{2} \mathrm{O}_{5} \mathrm{ha}^{-1}$. Surface irrigation was applied as per recommended scheduling at critical growth stages. Weeds in maize and legumes were controlled by practicing two intercultural operations with the help of a hand-held hoe. For weed control in wheat two herbicides were sprayed i.e. sulfosulfuron @ $25 \mathrm{~g} \mathrm{ha}^{-1}$ and metsulfuron @ $4 \mathrm{~g} \mathrm{ha}^{-1}$, respectively in $400 \mathrm{~L}$ of water at 30 days after sowing. A net plot of $14.4 \mathrm{~m}^{2}$ (maize) and $9.8 \mathrm{~m}^{2}$ (wheat) was harvested manually from the middle of the experimental plot leaving the border on all sides at physiological maturity with the help of sickles. All the other recommended package of practices were kept common in all the crops as per recommendation ${ }^{24}$. Yield and yield attributing characters were obtained by using methods as described by Bell and Fischer ${ }^{26}$.

Observations recorded. Grain yield was calculated from the net plot area and converted into $\mathrm{kg} \mathrm{ha}^{-1}$. Grains of maize, green gram, and black gram were taken as yield whereas green pods of cluster bean and cowpea were considered as yield. In the case of wheat, $\mathrm{HI}$ was calculated by dividing grain yield by biomass. The number of earheads per meter row length was counted at two places in each plot and converted to per $\mathrm{m}^{2}$. Thousand grains weight (TGW) was calculated by taking random grain samples and counted by using Contador electronic seed counter (Pfeuffer, Germany) and weighed. Layak et al. ${ }^{27}$ used various formulae to calculate intercrop productivity and efficiency and accordingly these formulae were used in the present study to arrive at the distinct trend.

System productivity. System productivity in terms of wheat equivalent yield WEY was calculated by multiplying yield with minimum support price/market price of each crop in a cropping sequence and subsequently adding and thereafter divided by the price of one-tonne wheat.

$$
W E Y=(\text { Yieldofintercropsxmarketpriceofintercrops/Marketpriceofwheat })
$$




\begin{tabular}{|c|c|c|c|c|c|c|c|c|c|c|c|c|}
\hline Effect & df & GY & BM & HI & SNPMS & TGW & GPS & GrPMS & WEY & Returns (\$) & Net returns (\$) & B:C ratio \\
\hline Year & 3 & $<0.001$ & $<0.001$ & $<0.001$ & $<0.001$ & $<0.001$ & $<0.001$ & $<0.001$ & $<0.001$ & $<0.001$ & $<0.001$ & $<0.001$ \\
\hline Treat & 12 & $<0.001$ & $<0.001$ & $<0.001$ & 0.045 & $<0.001$ & 0.017 & $<0.001$ & $<0.001$ & $<0.001$ & $<0.001$ & $<0.001$ \\
\hline Year $\times$ Treat & 36 & 0.021 & $<0.001$ & 0.002 & 0.058 & 0.011 & 0.010 & 0.021 & $<0.001$ & $<0.001$ & $<0.001$ & $<0.001$ \\
\hline
\end{tabular}

Table 2. Analysis of variance of maize + pulse-wheat intercropping system.

Land equivalent ratio (LER). LER is the relative area of the sole crop that would be required to produce the equivalent yield achieved by intercropping. It is the summation of the ratio of yield of intercrop to the yield of the sole crop. It was calculated as follows ${ }^{28}$ :

$$
\mathrm{LER}=\mathrm{LER}^{\mathrm{M}}+\mathrm{LER}^{\mathrm{L}}=\left(\mathrm{Y}^{\mathrm{ML}} / \mathrm{Y}^{\mathrm{MM}}+\mathrm{Y}^{\mathrm{LM}} / \mathrm{Y}^{\mathrm{LL}}\right)
$$

where $L_{E R}{ }^{M}$ and $L E R^{L}$ are the partial LER of maize and legumes, respectively. $Y^{M L}=$ Yield of first intercrop, $\mathrm{Y}^{\mathrm{LM}}=$ Yield of second intercrop, $\mathrm{Y}^{\mathrm{MM}}=$ Yield of first sole crop, $\mathrm{Y}^{\mathrm{LL}}=$ Yield of second sole crop.Monetary Advantage Index (MAI)

The MAI is computed by using the following formula:

$$
\mathrm{MAI}=\{(\mathrm{LER}-1) /(\mathrm{LER}) \times \text { value of combined intercrops }\}
$$

\section{Sustainability value index (SVI).}

$$
\mathrm{SVI}=(\mu-\delta) / \mathrm{Y}_{\max },
$$

where, $\mu=$ mean of particular treatment in monetary terms, $\delta=$ standard deviation of particular treatment in monetary terms and $\mathrm{Y}_{\max }=$ potential maximum monetary returns (by converting potential maximum yield in monetary terms) over the years. Sustainable value index was calculated as per procedure earlier reported ${ }^{29}$.

Economics. Maize, green gram, black gram, cluster bean, cowpea, wheat crops yield was multiplied by minimum support price (US \$187.5, 733.5, 710.5, 565.8, 131.6, 228.3 ton $^{-1}$, respectively) of these crops (ref for MSP from PIB, GOI). The wheat straw yield was also multiplied by the market rate $\left(\$ 32.9 \operatorname{ton}^{-1}\right)$ and added to get the gross return. Cost of cultivation was calculated by considering field preparation, seed, fertilizer, irrigation, transportation, herbicide application, the cost involved in harvesting and threshing of produce, management charges, the rental value of land, interest on fixed capital, depreciation cost of implements, and farm buildings. Net return was calculated by subtracting the cost of cultivation from gross returns. The benefit-cost ratio was calculated by dividing the gross return by the total cost of cultivation. To convert into US $\$$ gross return, cost of cultivation and net return were divided by prevailing exchange rate ( $\$=$ Rs 76$)$.

Statistical analysis. Analysis of variance (ANOVA) and ranking of treatments was completed using Tukey's Range test at 0.05 (5\%) level of significance. The General Linear Model (GLM) Procedure in SAS 9.3 version 6.1.7061 for Windows (Cary, NC, SAS Institute Inc., 2012) was used for statistical analysis.

\section{Results}

Analysis of variance. Intercropping treatments of various pulse crops with maize were having significant effect on all the traits recorded in wheat such as GY $(\mathrm{P}<0.001), \mathrm{BM}(\mathrm{P}<0.001), \mathrm{HI}(\mathrm{P}<0.001)$, SNPMS $(\mathrm{P}=0.045)$, TGW $(\mathrm{P}<0.001)$, GPS $(\mathrm{P}=0.017)$ and GrPMS $(\mathrm{P}<0.001)$. The intercropping combinations were also having a statistically significant effect on overall monetary returns parameters such as NR and $\mathrm{B}: \mathrm{C}$ ratio (Table 2).

Wheat yield and yield attributing parameters. Legume intercrops and sole crops were followed with wheat in the winter season at two levels of nitrogen fertility viz. recommended $\mathrm{N}$ rate $\left(150 \mathrm{~kg} \mathrm{~N} \mathrm{ha}^{-1}\right)$ and $25 \%$ less than RDF (112.5 $\mathrm{kg} \mathrm{N} \mathrm{ha}^{-1}$ ). The parameters under study were GY, BM, GPS, TGW, SpPMS, HI, GrPMS were non-significant except HI. MCowW75 combination yielded more than maize-wheat cropping sequence besides saving $25 \% \mathrm{~N}$.

System productivity. System productivity was measured in terms of WEY and it was found that, MCow75 treatment produced maximum WEY $\left(15.9 \mathrm{t} \mathrm{ha}^{-1}\right)$ followed by MCow100 $\left(15.8 \mathrm{t} \mathrm{ha}^{-1}\right)$ which were statistically similar (Fig. 2). All the intercrops recorded more WEY than the maize-wheat system. This showed that system productivity under intercrops was higher than sole maize-wheat or sole legume-wheat system.

Land equivalent ratio (LER). All the intercrops in this study showed more than 1.0 LER, suggesting more system productivity under intercrop conditions. Maximum LER was obtained under treatments MCow75 (1.71) followed by MCow100 (1.68) and the least LER of 1 was obtained under sole crops (Fig. 2). 

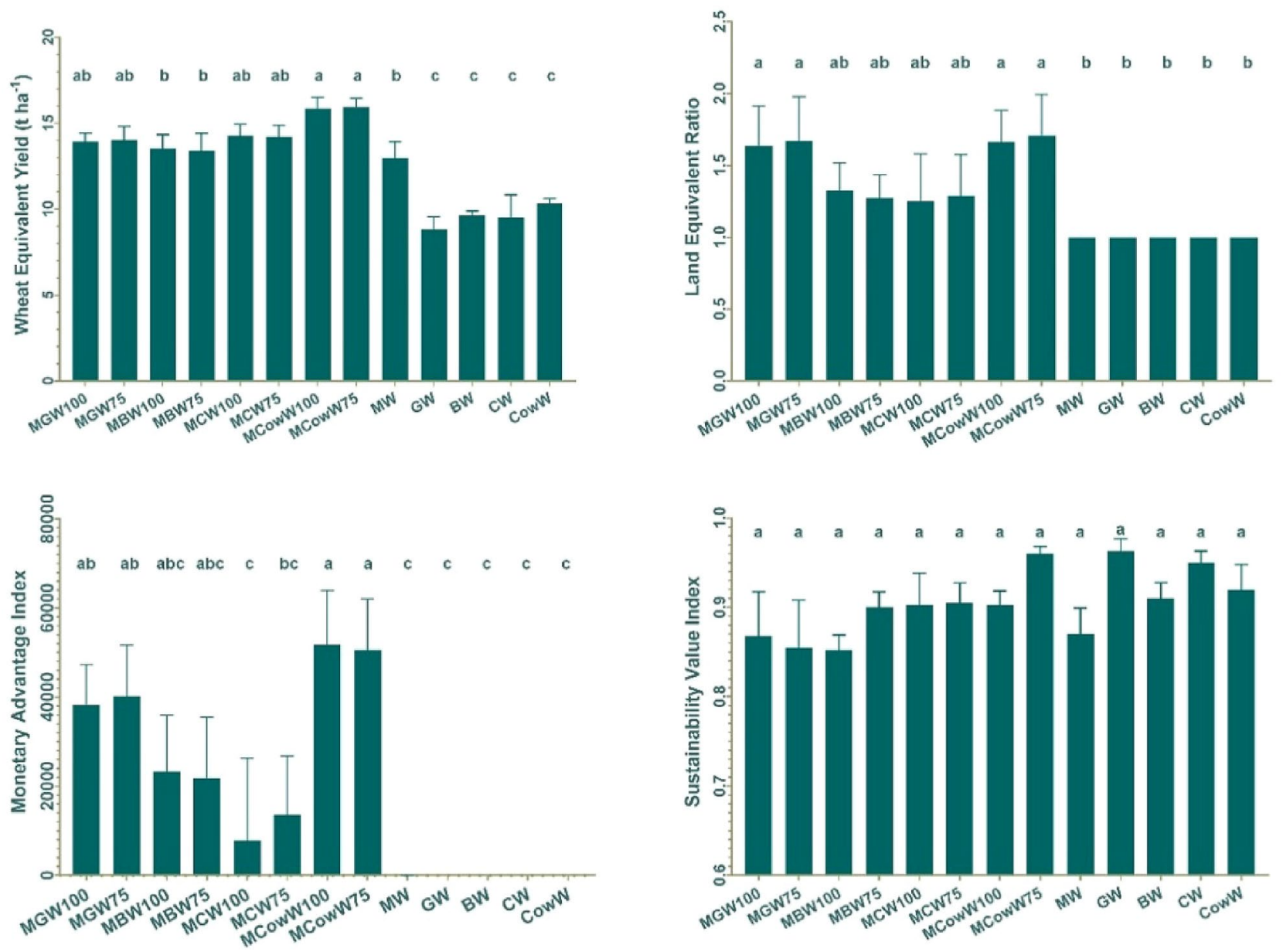

Figure 2. Effect of intercropping of legumes with Maize on competition indices.

Monetary advantage index (MAI). In this study, it was observed that maximum MAI was obtained by intercropping of cowpea under MCowW100 (MAI = 47,570) and MCowW75 (MAI=45,376) treatments. Minimum MAI was recorded under MCW100 (7326). Prices of both commodities were the same in the local market for green pod sale however higher cowpea production led to maximum MAI (Fig. 2).

Sustainability value index (SVI). Among the studied intercrops it was observed that all the intercrops showed more SVI than the sole maize-wheat cropping system. Maximum SVI (0.96) was obtained where cowpea intercropped with maize (Fig. 2). This confirms that cereal-cereal rotations are not performing better due to fatigued soil.

Soil health. The soil profile $0-15 \mathrm{~cm}$ depth was analyzed for $\mathrm{pH}, \mathrm{EC}, \mathrm{OC}$, available $\mathrm{N}, \mathrm{P}$, and $\mathrm{K}$ after completion of experiment and was compared with pre-experiment level. Tremendous increase in organic carbon (29.481.65\%), available N (3.89-25.20\%), available P (7.71-36.89\%), and available K (6.8-16.38\%) were recorded for the legume + maize intercropping treatments as compared to the initial level (Fig. 3). Cowpea intercrops with maize (MCowW) relatively enhanced organic carbon and $\mathrm{K}$ compared to other treatments.

Economics. Gross return (3641 $\left.\$ \mathrm{ha}^{-1}\right)$, the net return (1789 $\left.\$ \mathrm{ha}^{-1}\right)$, and B:C ratio (1.94) was maximum under MCowW75 (Fig. 4). All the intercrops exhibited higher gross return, net return and B:C ration than sole maize-wheat. Higher B:C ratio indicated that almost double income per \$ investment in this intercropping system. This confirms the hypothesis that cereal-cereal rotations are showing fatigue and it is time to utilize improved agronomic intensification strategies for generating higher returns in an environment-friendly way.

\section{Discussion}

Maize + legume intercrop is beneficial by enabling better radiation use ${ }^{5}$, nutrient partitioning between component crops $^{6}$, complementarity, and competitiveness ${ }^{30}$. In this study, the saving of $25 \% \mathrm{~N}$ in wheat when the legume was planted as an intercrop with maize in the previous season was the major finding. The addition of $\mathrm{N}$ by the pulses through biological nitrogen fixation (BNF) and enhanced carbon sequestration in the soil might be the reason for obtaining the equal yield between normal $\mathrm{N}$ and $-25 \% \mathrm{~N}$ treatments in wheat. Probably reduced $\mathrm{N}$ 


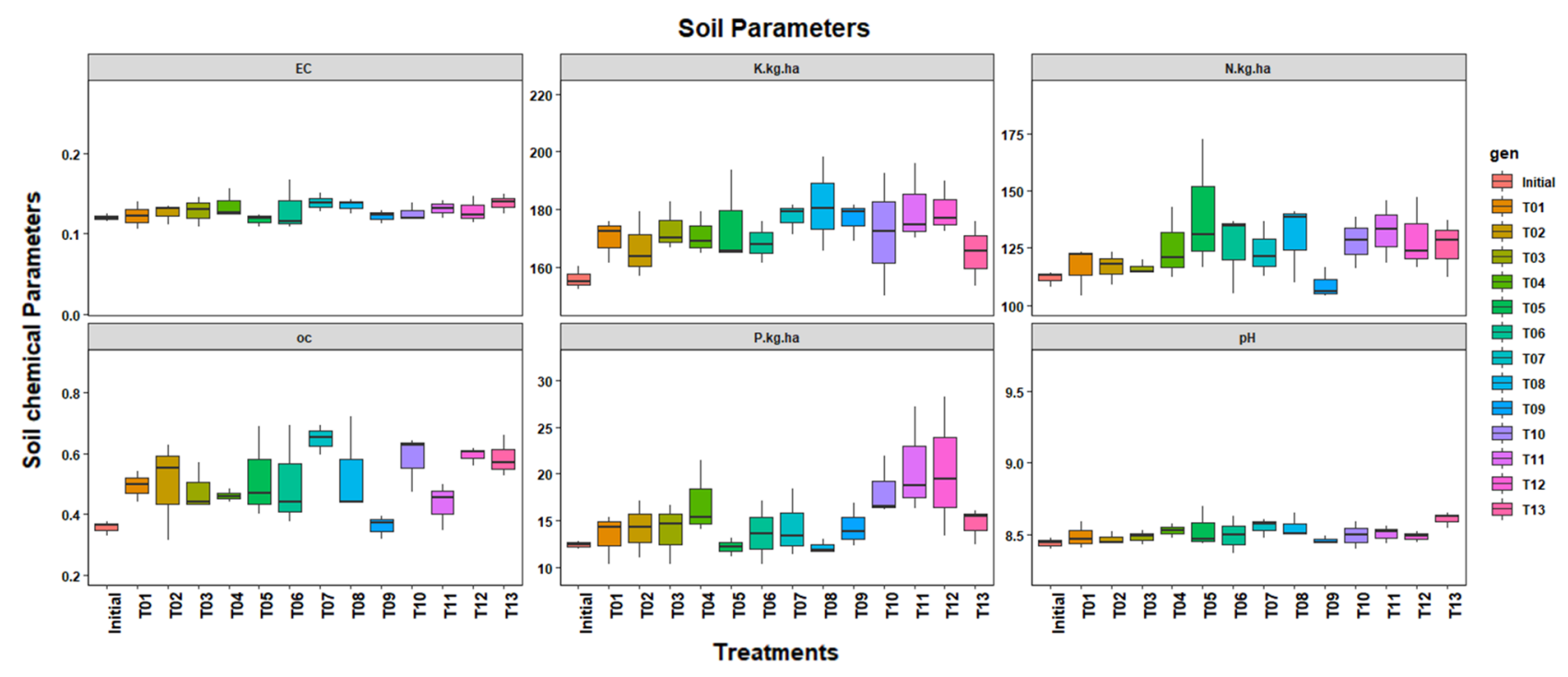

Figure 3. Effect of intercropping of legumes with maize on soil health measurements.

supply was compensated by the legume intercropping with maize leading to at par wheat yield when $25 \%$ lesser $\mathrm{N}$ was applied ${ }^{31}$. The BNF fixed $\mathrm{N}$ transferred to the succeeding crop was also reported earlier ${ }^{32}$ and further, Zao et al. ${ }^{33}$ observed that the favourable effects are more pronounced when soil N levels were low. Sharma and $\mathrm{Behra}^{34}$ reported that the $\mathrm{N}$ saving in the subsequent crop can also be attributed to $\mathrm{N}$ added through legume residues incorporation which varied from $11.5-38.5 \mathrm{~kg} \mathrm{ha}^{-1}$.

Higher system productivity indicated by greater WEY in treatments containing legume as an intercrop with maize followed by wheat compared to sole maize-wheat or sole legume-wheat was observed in this study. The relative advantage of cowpea (24.8\%) and green gram (16.1-29.9\%) intercropped with maize as compared to the sole maize was earlier reported by Sharma and Behera ${ }^{34}$. Further, equivalent yields were higher under the intercropping system as compared to sole crop in a study in baby corn and legumes in eastern India ${ }^{35}$. Moreover, Dwivedi et al. ${ }^{36}$ envisaged that equivalent yield increases under intercropping situations besides nutrient supplementation to maize crop. Maize intensification through green gram leading to higher WEY than sole rice-wheat crop was also earlier reported ${ }^{37,38}$. The productivity of intercropping was higher due to additional legume crop in wide row spacing maize crop, their remunerative price, and similar wheat yield with lesser nitrogen application.

In this study, Mcow 75 exhibited the highest LER of 1.71 indicating that there is a requirement of $71 \%$ additional land area for the production of similar GY by sole crop. Recently, Xu et al. ${ }^{6}$ conducted a meta-analysis of 90 research studies on maize and soybean intercropping and found that LER of $1.32 \pm 0.02$ whereas in our study it was 1.71 suggesting in Indian conditions intercropping is a better approach than taking individual crops. These results were also supported by earlier reports $s^{39,40}$ where maize and legume intercropping produced higher LER and economic returns than sole crop. Greater risk-bearing capacity of diversified farming was reported ${ }^{41}$. Attainment of more crop per unit area by intercropping of cereals with legume crop leading to higher land-use efficiency was also reported ${ }^{37,42,43}$. Higher LER was reported with maize + pea intercropping ${ }^{44}$ and maize + cowpea $^{9}$ than sole maize crop. In intercropping situations, MAI was more helpful in assessing the system productivity and its economic benefits ${ }^{36}$.

A higher sustainability value index plays an important role in maximizing the profit on a sustainable basis. MCowW 75 recorded higher SVI (0.96) and all the intercrop combinations showed more SVI than the sole maize-wheat system. These findings were supported by earlier research reports ${ }^{45}$ where inclusion of the green gram with rice-wheat produced a higher SVI of 0.92 .

Legumes intercropped with maize increased the organic carbon (27.61-79.13\%) and available N (6.7-28.59\%) compared to MW treatment. In line with our observations, Lin et al. ${ }^{46}$ also reported that green gram, soybean, and peanut intercropped with maize showed more than double soil $\mathrm{N}$ as compared to the sole crop. Similarly, Hödtke et al. ${ }^{47}$ observed that soil organic matter in the top layer of soil increased significantly and Cong et al. ${ }^{48}$ found soil organic carbon $(4 \pm 1 \%)$, soil organic $\mathrm{N}(11 \pm 1 \%)$, and $23 \%$ more root biomass with legume intercrop than sole crops, indicating more activities in the underground portion. Intercropping helps in maintaining the soil $\mathrm{N}$ balance on the positive side and can reduce the requirement of $\mathrm{N}$ fertilizer by about $26 \%$ on a global scale $\mathrm{e}^{49}$. Sharma and Behera ${ }^{34}$ observed that $\mathrm{N}$ addition through the legume residues ranged from $11.5-38.5 \mathrm{~kg} \mathrm{ha}^{-1}$ in the intercropped system, which improved the productivity of wheat. Thus, it can be said that intercropping of legumes with maize increased the soil fertility, which was utilized by the succeeding crop. Substantial reduction in dependency on external $\mathrm{N}$ fertilizer through the legume intercropping also has environmental benefits like reduction in transport cost, drudgery, fuel, and environmental pollution including global warming (one liter diesel burnt produce $\left.2.6 \mathrm{~kg} \mathrm{CO}_{2}\right)^{50}$. According to reports ${ }^{51,52} 1.2 \%$ of the total global primary energy is used for chemical production of $\mathrm{N}$ used as fertilizers through an energy-intensive chemical process. The saved $\mathrm{N}$ through maize-pulse intercropping indirectly helps in reducing energy consumption for $\mathrm{N}$ fertilizer synthesis which 

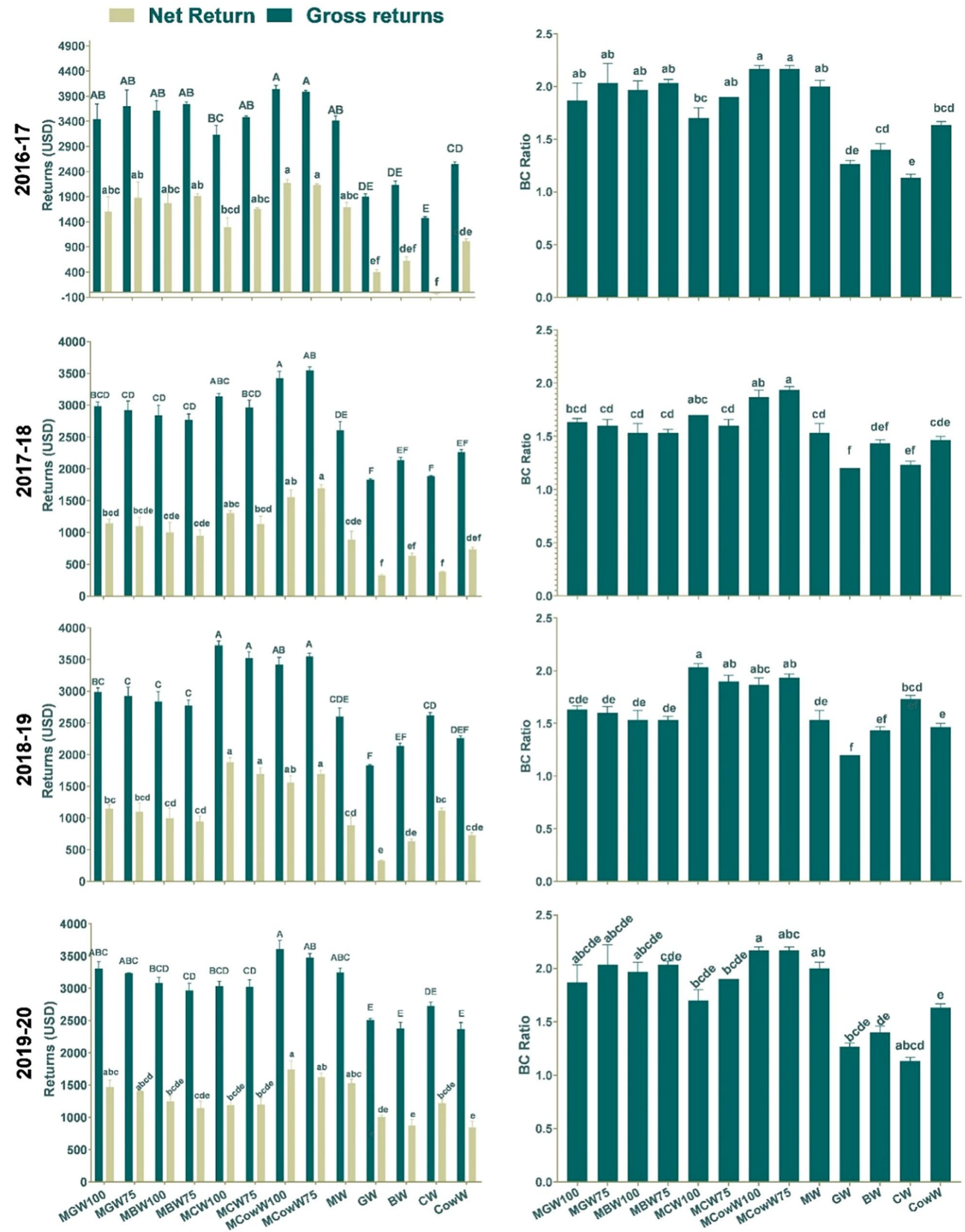

Figure 4. Returns (Gross and Net) and B:C ratio obtained under different intercropping treatments. 
otherwise would be available for alternate uses. Reduction in excess $\mathrm{N}$ usage would further help in maintaining water and air quality ${ }^{53}$.

Intercropping of the legume with maize produced higher economic returns and B:C ratio than in MW treatment. Yigezu et al. ${ }^{54}$ reported that legume-based rotations have clear economic advantages (48\%) over cereal monocropping and this was supported by several other workers ${ }^{34,39}$. Additionally, increased acreage under pulse and resulting production shall lead to cheaper availability of protein. Furthermore, the availability of cheaper pulses to poorer sections of society will enhance overall health and wellbeing. The results of this study have direct global implications in countries mainly dependent on maize-based cropping systems such as China, the USA, Brazil, India, Argentina, Indonesia, South Africa, and Ethiopia ${ }^{13}$. These maize-producing regions worldwide can become sustainable in maize production in an environment-friendly way by the practice of maize-pulse intercropping. Excessive $\mathrm{N}$ usage in agricultural production and resultant environmental contamination have been reported globally ${ }^{55}$ in general and specifically in maize-based cropping systems of the USA ${ }^{56,57}$, China ${ }^{58}$, Pakistan $^{59,60}$, and Brazil ${ }^{61}$ which could be substantially reducing their dependency on externally applied $\mathrm{N}$ through the practice of maize + pulse intercropping.

\section{Conclusions}

Based on 4 years of experiments, it was established that intercropping of legumes enhanced the LER, WEY, SVI, MAI as compared to MW treatment. MCowW75 attained LER of 1.71, suggesting $71 \%$ more area is needed by the sole crop to produce the same yield. Similarly, MCowW75 recorded SVI of up to 0.96, indicating higher system productivity and it produced maximum gross return $\left(\$ 3641 \mathrm{ha}^{-1}\right)$, net return $\left(\$ 1789 \mathrm{ha}^{-1}\right)$, and B:C ratio (1.94). In this study intercropping indices have shown the advantage, economy on the positive side, and soil health increased to a great extent. Growing intercrop with legumes increased the organic carbon (27.61-79.13\%) and available $\mathrm{N}$ (6.7-28.59\%) over to MW treatment. In this article, we ummarized that maize + legume intercropping was beneficial than monoculture and it saved $25 \% \mathrm{~N}$ in succeeding wheat crop. Future research may focus on the cropping system approach rather than a single crop. From a cropping system perspective, it may be concluded that intercropping with legumes can save a significant quantity of $\mathrm{N}$ which in turn reduces the cost of cultivation and can enhance soil health parameters.

Received: 5 March 2021; Accepted: 26 August 2021

Published online: 22 September 2021

\section{References}

1. Sharma, I., Tyagi, B., Singh, G., Venkatesh, K. \& Gupta, O. Enhancing wheat production-A global perspective. Indian J. Agric. Sci. 85, 3-13 (2015).

2. Srivastav, A. L., Dhyani, R., Ranjan, M., Madhav, S. \& Sillanpää, M. Climate-resilient strategies for sustainable management of water resources and agriculture. Environ. Sci. Pollut. Res. https://doi.org/10.1007/s11356-021-14332-4 (2021).

3. Fragoso, C. et al. Agricultural intensification, soil biodiversity and agroecosystem function in the tropics: The role of earthworms. Appl. Soil. Ecol. 6, 17-35 (1997).

4. Li, L., Tilman, D., Lambers, H. \& Zhang, F. Plant diversity and overyielding: Insights from belowground facilitation of intercropping in agriculture. New Phytol. 203, 63-69 (2014).

5. Li, S. et al. Estimating the contribution of plant traits to light partitioning in simultaneous maize/soybean intercropping. J. Exp. Bot. 72, 3630-3646 (2021).

6. $\mathrm{Xu}, \mathrm{Z}$. et al. Intercropping maize and soybean increases efficiency of land and fertilizer nitrogen use: A meta-analysis. Field Crops Res. 246, 107661 (2020).

7. Li, C. et al. Syndromes of production in intercropping impact yield gains. Nat. Plants 6, 653-660 (2020).

8. Liu, X. et al. Changes in light environment, morphology, growth and yield of soybean in maize-soybean intercropping systems. Field Crop Res. 200, 38-46 (2017).

9. Masvaya, E. N., Nyamangara, J., Descheemaeker, K. \& Giller, K. E. Is maize-cowpea intercropping a viable option for smallholder farms in the risky environments of semi-arid southern Africa?. Field Crop Res. 209, 73-87 (2017).

10. Namatsheve, T. et al. Maize-cowpea intercropping as an ecological intensification option for low input systems in sub-humid Zimbabwe: Productivity, biological N2-fixation and grain mineral content. Field Crops Res. 263, 108052 (2021).

11. Zhang, D. et al. Maize plant density affects yield, growth and source-sink relationship of crops in maize/peanut intercropping. Field Crops Res. 257, 107926 (2020).

12. Li, Y. et al. Maize/peanut intercropping increases photosynthetic characteristics, ${ }^{13} \mathrm{C}$-photosynthate distribution, and grain yield of summer maize. J. Integr. Agric. 18, 2219-2229 (2019).

13. FAOSTAT. FAOSTAT Statistical Database (2019).

14. Prasanna, B. M. et al. Molecular breeding for nutritionally enriched maize: Status and prospects. Front. Genet. 10, 1392 (2020).

15. Zuo, Y., Zhang, F., Li, X. \& Cao, Y. Studies on the improvement in iron nutrition of peanut by intercropping with maize on a calcareous soil. Plant Soil 220, 13-25 (2000).

16. McDermott, J. \& Wyatt, A. J. The role of pulses in sustainable and healthy food systems: Pulses in food systems. Ann. N. Y. Acad. Sci. 1392, 30-42 (2017).

17. Bisht, A. \& Kumar, A. Growth and instability analysis of pulses production in India. Int. J. Agric. Sci. 10, 6722-6724 (2018).

18. Guiducci, M., Tosti, G., Falcinelli, B. \& Benincasa, P. Sustainable management of nitrogen nutrition in winter wheat through temporary intercropping with legumes. Agron. Sustain. Dev. 38, 31 (2018).

19. Adarsh, S., John, J. \& Thomas, G. Role of pulses in cropping systems: A review. Agric. Rev. 40, 185-191 (2019).

20. Walkley, A. \& Black, I. A. An examination of the Degtjareff method for determining soil organic matter, and a proposed modification of the chromic acid titration method. Soil Sci. 37, 29-38 (1934).

21. Jackson, M. L. Soil Chemical Analysis (Prentice-Hall, 1958).

22. Olsen, S. R. Estimation of Available Phosphorus in Soils by Extraction with Sodium Bicarbonate (United States Department of Agriculture, 1954).

23. Merwin, H. D. \& Peech, M. Exchangeability of soil potassium in the sand, silt, and clay fractions as influenced by the nature of the complementary exchangeable cation 1. Soil Sci. Soc. Am. J. 15, 125-128 (1951).

24. Dhaliwal, H. S. \& Kular, J. S. Package of practices for the crops of Punjab. Punjab Agricultural University, Ludhiana. http://www. pau.edu/index.php?_act=manageLink\&DO=firstLink\&intSubID=83 (2014). 
25. Zadoks, J. C., Chang, T. T. \& Konzak, C. F. A decimal code for the growth stages of cereals. Weed Res. 14, 415-421 (1974).

26. Bell, M. \& Fischer, R. Guide to Plant and Crop Sampling: Measurements and Observations for Agronomic and Physiological Research in Small Grain Cereals (CIMMYT, 1994).

27. Layek, J. et al. Cereal+legume intercropping: an option for improving productivity and sustaining soil health. In Legumes for Soil Health and Sustainable Management (eds Meena, R. S. et al.) 347-386 (Springer, 2018). https://doi.org/10.1007/978-981-13-0253$4 \_11$.

28. Mead, R. \& Willey, R. W. The concept of a 'land equivalent ratio' and advantages in yields from intercropping. Exp. Agric. 16, $217-228$ (1980).

29. Singh, R. P. et al. Towards Sustainable Dryland Agricultural Practices (Central Research Institute for Dryland Agriculture, 1990).

30. Li, C. et al. Yield gain, complementarity and competitive dominance in intercropping in China: A meta-analysis of drivers of yield gain using additive partitioning. Eur. J. Agron. 113, 125987 (2020).

31. Choudhary, V. K., Dixit, A., SureshKumar, P. \& Chauhan, B. S. Productivity, weed dynamics, nutrient mining, and monetary advantage of maize-legume intercropping in the Eastern Himalayan Region of India. Plant Prod. Sci. 17, 342-352 (2014).

32. Guiducci, M., Tosti, G., Falcinelli, B. \& Benincasa, P. Sustainable management of nitrogen nutrition in winter wheat through temporary intercropping with legumes. Agron. Sustain. Dev. 38, 31 (2018).

33. Zhao, J. et al. Does crop rotation yield more in China? A meta-analysis. Field Crops Res. 245, 107659 (2020).

34. Sharma, A. R. \& Behera, U. K. Recycling of legume residues for nitrogen economy and higher productivity in maize (Zea mays)wheat (Triticum aestivum) cropping system. Nutr. Cycl. Agroecosyst. 83, 197-210 (2009).

35. Banik, P. \& Sharma, R. C. Yield and resource utilization efficiency in baby corn-legume-intercropping system in the Eastern Plateau of India. J. Sustain. Agric. 33, 379-395 (2009).

36. Dwivedi, A. et al. Potential role of maize-legume intercropping systems to improve soil fertility status under smallholder farming systems for sustainable agriculture in India. Int. J. Life Sci. Biotechnol. Pharma Res. 4, 145 (2015).

37. Tripathi, S. Bed planting for higher return in rice-wheat system. Indian Farm. 34, 18-21 (2008).

38. Tripathi, S. C., Chander, S. \& Meena, R. P. Phosphorus skipping effect on productivity, profitability and sustainability of rice-wheat cropping systems in Indo-Gangetic plains of India. Arch. Agron. Soil Sci. 65, 1134-1146 (2019).

39. Parimaladevi, C., Ramanathan, S., Kumar, N. \& Suresh, S. Evaluation of maize based intercropping systems in Thamirabarani basin of Tamil Nadu. J. Pharmacogn. Phytochem. 8, 4051-4056 (2019).

40. Mao, L. et al. Yield advantage and water saving in maize/pea intercrop. Field Crop Res. 138, 11-20 (2012).

41. Li, Y. et al. A global synthesis of the effect of water and nitrogen input on maize (Zea mays) yield, water productivity and nitrogen use efficiency. Agric. For. Meteorol. https://doi.org/10.1016/J.AGRFORMET.2019.01.018 (2019).

42. Agegnehu, G., Ghizaw, A. \& Sinebo, W. Yield potential and land-use efficiency of wheat and faba bean mixed intercropping. Agron. Sustain. Dev. 28, 257-263 (2008).

43. Dhar, P. C. et al. Interspecific competition, growth and productivity of maize and pea in intercropping mixture. Int. J. Agron. Agric. Res. 3, 5-12 (2013).

44. Zhao, C. et al. No-tillage reduces competition and enhances compensatory growth of maize (Zea mays L.) intercropped with pea (Pisum sativum L.). Field Crops Res. 243, 107611 (2019).

45. Tripathi, S. \& Singh, R. Effect of crop diversification on productivity and profitability of rice (Oryza sativa)-wheat (Triticum aestivum) cropping system. Indian J. Agron. 53, 27-31 (2008).

46. Lin, P.-H., Huang, M.-S. \& Chao, Y.-Y. Effects of various leguminous intercrops on maize yield. Maydica 63, 6 (2018).

47. Hödtke, M., Lopes de Almeida, D. \& Köpke, U. Intercropping of maize and pulses: An evaluation of organic cropping systems. Organ. Agric. 6, 1-17 (2016).

48. Cong, W.-F. et al. Intercropping enhances soil carbon and nitrogen. Glob. Change Biol. 21, 1715-1726 (2015).

49. Jensen, E. S., Carlsson, G. \& Hauggaard-Nielsen, H. Intercropping of grain legumes and cereals improves the use of soil $\mathrm{N}$ resources and reduces the requirement for synthetic fertilizer N: A global-scale analysis. Agron. Sustain. Dev. 40, 5 (2020).

50. Tripathi, S. C. Effective newer tillage options in rice-wheat system - an Indian perspective. J. Wheat Res. 2, 63-70 (2008).

51. Bicer, Y., Dincer, I., Vezina, G. \& Raso, F. Impact assessment and environmental evaluation of various ammonia production processes. Environ. Manag. 59, 842-855 (2017).

52. Sinha, S. K. et al. Nitrate starvation induced changes in root system architecture, carbon: Nitrogen metabolism, and miRNA expression in nitrogen-responsive wheat genotypes. Appl. Biochem. Biotechnol. 177, 1299-1312 (2015).

53. Robertson, G. P. \& Vitousek, P. M. Nitrogen in agriculture: Balancing the cost of an essential resource. Annu. Rev. Environ. Resour. 34, 97-125 (2009).

54. Yigezu, Y. A. et al. Legume-based rotations have clear economic advantages over cereal monocropping in dry areas. Agron. Sustain. Dev. 39, 58 (2019).

55. Móring, A. et al. Nitrogen challenges and opportunities for agricultural and environmental science in India. Front. Sustain. Food Syst. 5, 505347 (2021).

56. USDA-ERS. Table 7-Average U.S. Farm Price of Selected Fertilizers, 1960-2013 (2013).

57. US-EPA. National Greenhouse Gas Emissions Data: Draft Inventory of U.S. Greenhouse Gas Emissions and Sinks: 1990-2013. (2015).

58. Hartmann, T. E. et al. Yield and $\mathrm{N}$ use efficiency of a maize-wheat cropping system as affected by different fertilizer management strategies in a farmer's field of the North China Plain. Field Crop Res. 174, 30-39 (2015).

59. Mahmood, T., Malik, K. A., Shamsi, S. R. A. \& Sajjad, M. I. Denitrification and total N losses from an irrigated sandy-clay loam under maize-wheat cropping system. Plant Soil 199, 239-250 (1998).

60. Mahmood, T., Tahir, G. R., Malik, K. A. \& Shamsi, S. R. A. Denitrification losses from an irrigated sandy-clay loam under a wheatmaize cropping system receiving different fertilizer treatments. Biol. Fertil. Soils 26, 35-42 (1997).

61. Villalba, J., Otto, R., Trivelin, P. \& Leite, J. Fertilizantes nitrogenados: novas tecnologias. Inf. Agron. 148, 1-20 (2014).

\section{Author contributions}

S.C.T.: Project Incharge, conceived idea, execution of experiments, writing of manuscript.K.V.: Data analysis, drafting and editing manuscript.R.P.M.: Data recording and editing manuscript.S.C.: Lab analysis.G.P.S.: Post review inputs, Arranging funds for publication.

\section{Funding}

The research work was funded by Indian Council of Agricultural Research at Indian Institute of Wheat and Barley Research, Karnal, Haryana, India.

\section{Competing interests}

The authors declare no competing interests. 


\section{Additional information}

Correspondence and requests for materials should be addressed to S.C.T.

Reprints and permissions information is available at www.nature.com/reprints.

Publisher's note Springer Nature remains neutral with regard to jurisdictional claims in published maps and institutional affiliations.

(c) (1) Open Access This article is licensed under a Creative Commons Attribution 4.0 International License, which permits use, sharing, adaptation, distribution and reproduction in any medium or format, as long as you give appropriate credit to the original author(s) and the source, provide a link to the Creative Commons licence, and indicate if changes were made. The images or other third party material in this article are included in the article's Creative Commons licence, unless indicated otherwise in a credit line to the material. If material is not included in the article's Creative Commons licence and your intended use is not permitted by statutory regulation or exceeds the permitted use, you will need to obtain permission directly from the copyright holder. To view a copy of this licence, visit http://creativecommons.org/licenses/by/4.0/.

(C) The Author(s) 2021 